\title{
Analyse of the Relation between the Coloured Progressive Matrices Test and the Cognitive Abilities Test Form-6 in the Preschool Period of Gifted Children
}

\author{
Ahmet Bildiren ${ }^{1} \&$ Gözde İnal Kızıltepe ${ }^{1}$ \\ ${ }^{1}$ Education Faculty, Adnan Menderes University, Turkey \\ Correspondence: Gözde İnal Kızıltepe, Education Faculty, Adnan Menderes University, Turkey.
}

Received: May 1, 2018 Accepted: May 13, $2018 \quad$ Online Published: May 15, 2018

doi:10.5539/jel.v7n4p215 URL: https://doi.org/10.5539/jel.v7n4p215

\begin{abstract}
The diagnosis of preschool gifted children in Turkey has just come up in recent years. Therefore, there is a need for measurement tools that can be applied during the diagnosis phase of preschool gifted children. The aim of this study was to diagnose the relation between the non-verbal and culture-independent Colour Progressive Matrices Test that's frequently used in the international field during the preschool period and the Cognitive Ability Test Form-6, which is a group of tests that assess the cognitive abilities of children in different age groups including verbal, quantitative and nonverbal dimensions, and which is also used in the diagnosis of gifted children in the international arena, to contribute to the diagnosis of preschool gifted children. The sample of the study consisted of 125 children who attended nine preschool education institutions determined by the socio-economic level (low-middle-high) in the central district Efeler of the province Aydın. The mean age of the children is 4.9 and the standard deviation is .8. 49 of the children were girls (39.2\%) and 76 were boys (60.8\%). Colour Progressive Matrices Test and Cognitive Abilities Test Form-6 were implemented individually to the children. The study revealed that the tests had correlation, the verbal and quantitative dimensions of the Cognitive Abilities Test Form-6 were found to predict the nonverbal cognitive ability of the Coloured Progressive Matrices Test.
\end{abstract}

Keywords: gifted children, preschool period, the colored progressive matrices test, the cognitive abilities test form-6

\section{Introduction}

Developments in the identification of superior abilities have been mainly revealed from research related to the academic life after the preschool period (Pfeiffer, 2003; Pfeiffer \& Petscher, 2008). However, as the value of education in the early childhood period increased, it became important to identify and educate gifted children early (Pfeiffer, 2002; Pfeiffer \& Jarosewich, 2003; Pfeiffer \& Petscher, 2008; Robinson \& Weimert, 1990; Sankar-DeLeeuw, 2002; Shaklee \& Hansford, 1992). This importance has revealed that tendencies and characteristics are observable in this age group of children (Clark, 2002; Davis \& Rimm, 2004; Renzulli et al., 2002). For example, Tannenbaum (1992) mentioned three basic signs of superiority in infants and young children. These are attention, memory and early language development. Liu and Lien (2005) defended that normal childhood play, even finding their activities boring, could be a sign of superiority.

Cognition is seen as a critical factor in the indicators of superiority in preschool period (Clark, 2002; Davis\& Rimm, 2004). The interests of the superior individual are varied and he can be a curious about everything. Asks questions about everything and approaches everything questioning (Bildiren, 2017; Bloom, 1982; Clark, 2002; Davis \& Rimm, 2004; Renzulli et al., 2002). One of the characteristics of these young aged superiors is advanced language development. They have a large vocabulary range at the age of 2 to 3 years old and use complex sentence structures. Early speech is the way children express their thoughts and learn from questions. They are in a verbal interaction with their family members when their peers cannot come to this point yet (Clark, 2002; Silverman, 1997-2004). Early reading, the ability of empathy and emotional intensity are also common features (Clark, 2002; Robinson, 1987; Walker, Hafenstein, \& Crow-Enslow, 1999).

Preschool children, who have the potential to be superior, can show characteristics like the use of advanced vocabulary and/or early reading, asynchronous development, persistent observation and curiosity, having 
extraordinary information, long and intensive concentration, art predisposition, more self-commitment than their peers, understanding complex concepts, perception of relationships and abstract thinking (Clark, 2002; Smutny, 1998). Preschool gifted children expose superior cognitive abilities besides these features. These metacognitive abilities occur when the child is more interested in a task. The superior memory allows them to learn much more quickly, solve complex problems, and even remember the most detailed events (Renzulli et al., 2002; Porter, 2005).

The observation of these features from the early ages made the issue of early recognition of gifted children a current issue. However, limited research on preschool gifted children also limits their diagnostic researches. In a survey of 64 experts in the field of superiority and under the direction of Pfeiffer (2003), it was stated that diagnosis is a critical issue and that early diagnosis and intervention is important. One of the questions asked in the survey is "what do you think about the three best methods used to diagnose gifted children?" The 4 answers received in the research revealed the most important problem in diagnosing gifted children. The first of these is the lack of consensus on how gifted children have to be diagnosed, the other one are the problems of the diagnostic process - the lack of multiple criteria, another is the doubtful validity of existing instruments and the last one is the fact that minority groups cannot be adequately represented. $41 \%$ of the 64 authorities reported that the diagnostic process was problematic. The responses also set out a consensus on the need for the diagnosis of young children (Pfeiffer, 2003).

To minimise diagnosis problems in preschool period, many researchers argue that diagnosis should combine multiple approaches and become a system in which the levels of gifted children are better diagnosed (Burns, 1990; Johnsen, 2008; Louis et al., 1991; Wortham, 2005). Accordingly, it is revealed that during the diagnosis process beneficial information about children, interviews, anecdotal records and families, observations of teachers, children's work samples, interest evaluation test scores and performance ratios should be used (Cohen; 1989, Wolfle, 1989).

Recommended practice guidelines support the use of multiple criteria for the evaluation of superior and early childhood special education (Akarsu, 2001; Karnes, Shaunessy \& Bisland, 2004; NAGC-CEC, 2006; Sandall, Hemmeter, Smith, \& McLean, 2005). It is particularly defended to use formal and informal evaluations together in the diagnosis. Formal evaluation includes norm-referenced tests that are standardized. Informal evaluators are the teachers who educate the children who make diagnoses and the families of preschool children who contribute. It has been shown that informal assessment is useful for children's education and for intervention plans. However, it is defended that this planning should be family-centred, open and comprehensive (McWilliam, 2005).

The most recommended productive practice for diagnosing gifted children consists of three phases in which formal and informal assessment instruments are used together. These are the stage of candidacy, the stage of diagnosis and the stage of selection-placement (Johnsen, 2009). At each stage, with the information that is collected it is determined whether the child has the criteria to pass to another stage.

In Turkey, the criteria and observation forms to be used in the nomination in the first step, the measuring instruments to be used in the diagnosis and the selection and placement criteria should be determined for early diagnosis of gifted children at preschool level. In the first step, the development of measurement tools for family and teachers according to the developmental characteristics of gifted children in preschool period will ensure that children eligible for diagnosis are nominated (Cohen, 1989; Louis, Lewis \& Feiring, 1991; McWilliam, 2005; Wortham, 2005).

In the second stage objective measurement tools are needed. In Turkey the Basic Abilities Test (5-7) in preschool period, the Goodenough-Harris Draw-a-man Test, Peadody Picture Vocabulary Test and The Bender Visual Motor Gestalt Test is used (Öner, 1997; Özgüven, 2000). However, many of these tests were made in the 70s and no further revision studies were done. One of the important steps of test standardization is to determine the values obtained from the norm groups. The test scores obtained from the application are evaluated according to the norms reflecting the acquisition of the standardization group. An important feature of norms is that it is relative in terms of time and space (Öner, 1997). The reliability of the test values is questioned while approximately 40 years past the adaptation study of these used tests.

It is not only important for gifted children, but also for all children, that the needs of current tests are fulfilled, especially in the preschool period. In this regard, the MEB has completed the adaptation of the Kaufman Brief Intelligence-2 Test (KBIT-2) for use in guidance and research centres within the scope of the Special Education and Guidance Services General Directorate Special Education Empowerment Project (ÖZEGEP) and began practitioner training (MEB, 2015). Currently in Guidance and Research Centres in Turkey, it is planned to use the Kaufman Brief Intelligence-2 Test as the current diagnostic tool. 
Karadağ, Karabey and Pfeiffer (2016) applied adaptation, reliability and validity studies of the "Gifted Rating Scale Preschool Kindergarten Form" measuring instrument on 390 children to determine the superior talent potential of preschool children between 4 and 6 years of age. With this measuring tool, preschool gifted children who are in the first stage of diagnosis can be shown as candidates.

Another test that is gained in the field is Turkey's Anatolia Sak Intelligence Scale, which is the first domestic intelligence test. The reliability and the validity of the test were made with 4641 children aged 4-12 years. The test has general intelligence index, verbal potential index, visual potential index, memory capacity index, verbal IQ, visual IQ, verbal short memory index, visual spatial memory index profiles (https://www.projeiq.com/)

Between the tests that are independent form culture and language, the Coloured Progressive Matrices Test (CPM) is the first test that comes in mind according to the litterature and a study of reliability and validity was exercised on 640 children aged 4-6 in the study of Bildiren, Kargin and Korkmaz (2017) and on 925 children aged 3-9 years in the study of Bildiren (2017). With these studies, non-verbal cognitive abilities of children in the preschool period can be evaluated independently of culture and can be used in the second stage of diagnosis.

In addition, the Cognitive Abilities Test Form 6 (CogAT Form 6), which is frequently used to assess the level of achievement of children from different age groups including the preschool period in the international literature in verbal, quantitative and nonverbal reasoning and problem solving abilities, is a group of tests that are often used during the diagnosis phase of gifted children, especially in the United States. (Cao, Jung \& Lee, 2017; Carman, Walther \& Bartsch, 2018; Lohman \& Hagen, 2003; Lohman, Korb \& Lakin, 2008; Yang, 2009). The validity and reliability study in Turkey of this test was conducted by İnal (2011) on 380 children at the age of 61-72 months.

In Turkey, the diagnosis of preschool gifted children came up in recent years. (Alemdar, 2009; Bildiren, 2016; Dağlığlu, 2002; Karadağ, 2015; Kurt, 2008; Selçuk-Bozkurt, 2007; Suveren, 2006). In some part of these studies, gifted children were determined by existing scales and in other parts by new scale development studies. However, like Pfeiffer (2003) mentions, there is no consensus for the diagnosis of preschool gifted children in Turkey and at the same time; there is a need for measuring means for each stage of the diagnosis. However, the increase of the tests brings the following question with it. According to which test will a superior ability be given? Investigations are continuing to answer this question. (Lewis et al., 2007; Lohman et al., 2008; Schroth \& Helfer, 2008). Although the results of the study differ, the use of more than one means of measurement and the common use of non-verbal and verbal tests are suggested. When foreign literature is studied, it is seen that different tests are used together in the diagnosis of preschool gifted children as well as of children in different age groups (Lohman et al., 2008; Cao, Jung \& Lee, 2017). From this point, in this study, it is aimed to investigate the relation between the non-verbal and culturally independent CPM, which is frequently used in the international literature during the preschool period and the CogAT Form-6, which is a group of tests evaluating the cognitive abilities in verbal, quantitative and non-verbal dimensions of children in different age groups, including the preschool period and which is also used in the international literature to diagnose gifted children. For this purpose, the answers for following questions were searched:

1) Is there a significant relationship between the CPM sets and the verbal, quantitative and nonverbal dimensions of the CogAT Form-6?

2) Is there a significant relationship between the total score of the CPM and the verbal, quantitative, and nonverbal dimensions of the CogAT Form-6?

3) Is the verbal and quantitative dimension of CogAT Form-6 significantly predicting the results of the CPM?

\section{Method}

\subsection{Research Model}

This study is in the relational screening model. The relational screening model is a research model aimed at determining the presence or degree of exchange between two or more variables (Crano \& Brewer, 2002; Karasar, 2006). Accordingly, it was examined whether there was a meaningful relationship between the CPM and the CogAT Form- 6 and which dimensions of the CogAT Form- 6 are predicting the non-verbal cognitive ability.

\subsection{Participants}

The sample of the study consisted of 125 children who attended 9 preschool education institutions determined by the socio-economic level (low-middle-high) of the central district Efeler of the province Aydin. The mean age of the children is 4.9 and the standard deviation is .8 .49 of the children were girls (39.2\%) and 76 were boys $(60.8 \%)$. Children who attend preschool education institutions are determined by random assignment. 
Sampling was used individually to the included children in both tests used to collect data in the study.

\subsection{Data Collection Tools}

Coloured Progressive Matrices Test: The Coloured Progressive Matrices Test (CPM), which was used to diagnose the cognitive level in preschool period, was developed for the evaluation of mental development and intellectual maturity. Raven carried out the first standardization work of CPM in 1949 in Dumfries, England. The test was formed by 39 articles. The sampling group consisted of 627 children aged 5-11 years. This standardization test showed a retest reliability of .80. After this study the classical form of the test was formed. In 1982, it was applied to 598 children in a follow-up norm. Besides the UK, the norm studies were applied for the standardization of CPM in America, France, Canada, Italy, Hong Kong, India, Germany (Cotton et al., 2005).

The widespread use has caused the memorization of test items and made it difficult to keep the assessment under control. Especially test subjects were taught to children for ensuring them to participate in training programs applied to gifted children. That is why the CPM was revised as a parallel form in 1998 in order to eliminate this problem (Raven et al., 1998).

In 1998, the CPM was revised again in a parallel form (Raven et al., 1998). The CPM, that is revised and arranged as a parallel form, consisted of a total of 36 pieces including 3 sets of 12 each. These have been named as $\mathrm{A}, \mathrm{AB}$ and $\mathrm{B}$. The matrices have been designed to be used in anthropological and clinical studies applied on small children and elderly people. In addition, the test can also be easily applied to people with physical disabilities, hearing impairments and those who cannot understand the spoken language and those who cannot speak (Raven et al., 1998).

Bildiren (2017) carried out the reliability and validity study in the 3-9 year old sample group of the Coloured Progressive Matrices Test in Turkey. The sample group of the study consisted of a total of 925 children (433 girls and 492 boys). The Cronbach alpha coefficient for the whole scale was determined as 0.83 . The Spearman Brown two split-half correlations were determined as .80. A sampling CPM Test $(n=63)$ was applied in four week intervals. A moderate, positive and significant relationship was determined between the CPM Test total test and Test-re-test results $(\mathrm{r}=0.611, \mathrm{p}<.01)$. A high significant correlation was also found between the CPM total test and the Bender Test results $(\mathrm{r}=0.703, \mathrm{p}<.01)$ and a moderately significant correlation was found between the results of the CPM Test and the TONI-3 Test $(\mathrm{r}=0.643, \mathrm{p}<.01)$.

Cognitive Abilities Test Form 6 (CogAT Form 6): The Cognitive Abilities Test developed by Lohman and Hagen in 2000, aims to evaluate the level of achievement of children aged 5-18 in reasoning abilities by using verbal, quantitative and non-verbal abilities (visual-spatial abilities) (Lohman \& Hagen, 2003; İnal \& Ömeroğlu, 2011). The (Alp \& Diri, 2003) test that was developed by using the intelligence theories that emerged in the framework of the traditional psychometric approach, was based on Vernon's Hierarchical Models of Abilities, that is based on cognitive abilities in hierarchical models, and on Cattell and Horn's Theory of Fluid and Crystallized Abilities (Lohman \& Hagen, 2002; İnal, 2011).

The Cognitive Abilities Test consists of two batteries, the Primary and Multi-Level Batteries, prepared for different age groups. The Primary Battery contains Level 1 and Level 2 tests that measure three different abilities, verbal, quantitative and nonverbal, prepared for children up to the second grade of primary school. The Level 1 test is used for the nursery class and the elementary school grade 1 . The CogAT Form-6, which can be applied as an individual or group test, consists of 120 questions evaluating the ability of reasoning in verbal, quantitative and nonverbal dimensions. Each sub-dimension of the test consists of two sub-tests, in which the multiple-choice answers are shown as pictures (İnal \& Ömeroğlu 2011).

In the norm test on 45.265 children aged between 61-72 months in America of the CogAT Form-6, the reliability coefficient for the whole test according to the split-half reliability was .94, between .96 and .95 (Lohman \& Hagen, 2003). In Turkey, the reliability and validity study in the 5-6 aged sample group for the Cognitive Abilities Test was made by Inal (2011). The sample of the study consists of 380 children aged 61-72 months. The KR-20 reliability coefficient for the whole scale is 0.91 . A sampling $(n=80)$ CogAT Form-6 was applied in four weeks. A high level, positive and significant correlation was determined between the total of CogAT test and the Test-re-test results $(\mathrm{r}=0.98, \mathrm{p}<.01)$.

\subsection{Data Analysis}

The Pearson Moment bidirectional correlation analysis was used in the study to determine if there is a linear correlation between the CPM Test and the CogAT Form-6 and Multiple Regression Analysis Techniques were used to determine the power to predict non-verbal cognitive ability of the verbal and quantitative dimension of the CogAT Form-6. The significance level in the study was accepted as .01. 


\section{Results}

Table 1. The correlation between the CPM Test and the CogAT Form-6

\begin{tabular}{llll}
\hline & CogAT Form 6 & CogAT Form 6 & CogAT Form 6 \\
& Verbal Battery & Quantitative Battery & Nonverbal Battery \\
\hline CPM SET A & $.35^{* *}$ & $.24^{* *}$ & $.27^{* *}$ \\
CPM SET AB & $.43^{* *}$ & $.45^{* *}$ & $.51^{* *}$ \\
CPM SET B & $.43^{* *}$ & $.46^{* *}$ & $.43^{* *}$ \\
CPM TOTAL & $.51^{* *}$ & $.50^{* *}$ & $.52^{* *}$ \\
\hline p $<0.01$. & &
\end{tabular}

When examining Table 1, it was found that there was a significant correlation between the CPM Test SET A and the CogAT Form- 6 verbal dimension scores $(\mathrm{r}=0.35, \mathrm{p}<.01)$, the CogAT Form- 6 quantitative dimension scores $(\mathrm{r}=0.24, \mathrm{p}<.01)$ and the CogAT Form- 6 nonverbal test $(\mathrm{r}=0.24, \mathrm{p}<.01)$. There was a significant correlation between the CPM Test SET AB and CogAT Form- 6 verbal dimension scores $(r=0.43, p<.01)$, CogAT Form- 6 quantitative scores $(\mathrm{r}=045, \mathrm{p}<.01)$, CogAT Form 6 non-verbal test scores $(\mathrm{r}=0.51, \mathrm{p}<.01)$. A significant correlation was found between CPM Test SET B and the CogAT Form- 6 verbal dimension scores $(r=0.43, p<.01)$, the CogAT Form- 6 quantitative dimension scores $(\mathrm{r}=0.46, \mathrm{p}<.01)$, the CogAT Form- 6 non-verbal dimension $(r=0.43, p<0.01)$. A significant correlation was found between the CPM Test total scores and the CogAT Form- 6 test verbal dimension scores $(\mathrm{r}=0.51, \mathrm{p}<.01)$, the CogAT Form-6 quantitative dimension scores $(\mathrm{r}=0.50, \mathrm{p}<.01)$ and the CogAT Form- 6 nonverbal dimension scores $(\mathrm{r}=0.52, \mathrm{p}<.01)$.

Table 2. Results of standard multiple regression analysis on the prediction of coloured progressive matrices test total scores

\begin{tabular}{llllllll}
\hline Variable & $\mathrm{B}$ & Standard Error & $\beta$ & $\mathrm{T}$ & $\mathrm{p}$ & $\begin{array}{l}\text { Binary } \\
\mathrm{R}\end{array}$ & $\begin{array}{l}\text { Partial } \\
\mathrm{R}\end{array}$ \\
\hline Constant & 4.424 & 1.917 & & 2.308 & .023 & & \\
Verbal & .300 & .087 & .323 & 3.449 & .001 & .51 & .297 \\
Quantitative & .219 & .067 & .309 & 3.293 & .001 & .50 & .285 \\
\hline $\mathrm{R}=.567$ & 2 & & & & & \\
$\mathrm{~F}=(2,123)$ & $\mathrm{R}=321$ & & & & & & \\
& $\mathrm{P}=.000$ & & & & & & \\
\hline
\end{tabular}

When examining the binary and partial correlations between predictor variables and dependent variables, it is seen that there is a moderate correlation between the CogAT Form-6 verbal dimension and the Coloured Progressive Matrices Test $(\mathrm{r}=.51)$, but when the other variable is controlled, the correlation between the two variables appears to be $r=.29$. There is a moderate correlation between the Cognitive Abilities Test Form- 6 quantitative dimension and the Coloured Progressive Matrices Test $(r=.50)$. However, when the other variable is controlled, it is seen that this correlation is calculated as $\mathrm{r}=.28$.

There is a moderate and meaningful correlation between the CogAT Form- 6 test and the verbal and quantitative dimension variables. The verbal and quantitative dimension of the CogAT Form- 6 describes about $32 \%$ of the CPM Test, in other words, the nonverbal cognitive ability.

\section{Discussion}

In this study, the relationship between the CPM and the CogAT Form-6, which can be used in the diagnosis of children with superior ability in preschool period, was investigated and the results of the research showed that the tests correlated and that the CogAT Form- 6 quantitative and verbal dimensions predicted the non-verbal cognitive ability of the CPM.

In order to be able to evaluate the tendencies and cognitive abilities of gifted children during the diagnosis phase, the children are admitted individually or in small groups (Johnsen, 2009). However, it can be misleading to diagnose according to a single intelligence test when it comes to preschool children. When considering the developmental characteristics of children between the ages of 3-6, the child may not exhibit the desired performance for any reason (getting bored, distraction, unwillingness, etc.). For this reason, the combination of different tests during the diagnosis phase may contribute to correct diagnosis. When the relationship levels of the CPM Test, which measures the nonverbal cognitive ability applied in the research group, and the CogAT Form-6, 
are taken into consideration, these two tests can be used during the diagnosis phase to identify gifted children in the preschool period. A child who does not perform for any reason on a test can be identified by another test.

The CPM Test used in the study measures children's non-verbal abilities. This test is often used in the diagnosis of gifted children in the early ages (Cotton et al., 2005). Lohman et al. (2008) It is said that the non-verbal Coloured Progressive Matrices Test (CPM), the Naglieri Nonverbal Ability Test (NNAT) and the Nonverbal Battery of Cognitive Abilities Test are often used to identify preschool gifted children who speak English in the US and who are new English learners. Again, the need to apply non-verbal tests such as CPM, NNAT, Nonverbal Battery of CogAT is emphasized to English learners to ensure that the abilities can be measured fairly (Lohman et al., 2008). Non-verbal measures are designed to create opportunities for children, who demonstrate linguistic, cultural and ethnic differences, to show their potential (Kirschbaum, 1998; Nagleri \& Ford, 2005). This assumption is not supported in some studies. As a reason for this, due to insufficient norms of evaluations of measuring tools made by Raven (1970), children get higher scores than needed and as a result of this there are inconsistent placements (Lohman et al., 2008). However, Lewis, et al. (2007) found that CPM recognizes a child with more ethnic differences than NNAT, in accordance with its superior programs. It has been determined that children learn something from the previous question in the CPM Test and it is more effective than NNAT in diagnosis of minority students because of the their nature of continuity.

There are other concerns about non-verbal tests used to diagnose gifted children. In addition, this is the measurement structure of the tests. It is argued that this structure alone is not a good predictor of academic success. It is stated that a better diagnostic method is a method in which verbal and quantitative abilities measuring academic ability are evaluated together (Lohman et al., 2008). In this respect, the support of verbal tests such as CPM, NNAT with non-verbal tests, makes it easier to reach the diagnosis, the second stage of diagnosis. In this respect, the verbal and quantitative dimension of the CogAT Form- 6 used in the research, can also contribute at the same time to measure the academic abilities of the children.

In the research results, we can see that the verbal and quantitative dimensions of the CogAT Form- 6 have a significant correlation with the nonverbal CPM, where the cognitive ability is measured. This result shows that although non-verbal cognitive abilities are considered independent of verbal and quantitative abilities, we can see their relations with each other in the research group. In their study, Lohman et al. (2008) have also examined the correlations between the verbal, quantitative and nonverbal dimensions of the CogAT and the Raven Standard Progressive Matrices (Raven) to determine which of the three commonly used non-verbal tests are more valid in the diagnosis of gifted children. According to this, there is a moderate correlation between the verbal dimension of the CogAT and the Raven Test, a moderate correlation between the quantitative dimension of the CogAT and the Raven Test and a strong correlation between the nonverbal dimension of the CogAT and the Raven Test in the sample consisting of non-English-language learning elementary children $(\mathrm{n}=664)$. And there is a low correlation between the verbal dimension of the CogAT and the Raven Standard Progressive Matrices Test, a moderate correlation between the quantitative dimension of the CogAT and the Raven Test and a high correlation between the nonverbal dimension of the CogAT and the Raven Test in the sample consisting of English-language learning elementary children $(n=426)$. The results of the study conducted by Lohman et al., (2008) generally support the findings obtained from this study.

Relationships between performance IQ and verbal IQ were similarly tested in different studies with intelligence tests (Çelik et al., 2017; Yiğit et al., 2017). This may be due to the complex nature of intelligence. It is not easy to explain intelligence and superior ability (Stenberg, 2018). In this context, the evaluation of non-verbal cognitive ability together with the quantitative and verbal ability can lead us to a better point when determining intelligence.

Many theorists have come up with various ideas about the concept and diagnose of superior ability (Gagne, 2003; Gardner, 2003; Sternberg, 2003; Renzullli, 1984; Tannenbaum, 2003). Opinions vary. However, the large majority agree that for some children the potential can be diagnosed, and that when this potential evolves according to different characteristics, superiority can be examined in broad categories. Even when the two tests discussed in the study are applied together, it is necessary to evaluate different factors such as product and portfolio files according to current multidimensional superior capability approaches (Karnes, et al., 2004; NAGC-CEC, 2006; Sandall, et al., 2005). However, multidimensional approaches do not reject objective measurement tools. The tests are an important factor for multiple evaluation criteria. It may be suggestible to use similar tests in preschool period to maintain the diagnosis objectively. 


\section{References}

Akarsu, F. (2001). Üstün yetenekli çocuklar aileleri ve sorunları. Ankara: Eduser Yayınları.

Alemdar, M. (2009). Erken çocukluk dönemindeki üstün yetenekli çocukların belirlenmesinde ebeveyn, ögretmen ve uzman görüşlerinin karşılaştırılması. Yayınlanmamış yüksek Lisans tezi. Gazi Üniversitesi Eğitim Bilimleri Enstitüsü, Ankara.

Alp, E. İ., \& Diri, A. (2003). Bilişsel yetenekler testi'nin (CogAT®) ana sınıfı ve birinci sınıf öğrencileri için kurultu geçerliliği çalışması. Türk Psikoloji Dergisi, 18(51), 19-31.

Bildiren, A. (2016). Proje temelli yaklaşıma dayalı erken müdahale programının üstün yetenekli çocukların problem çözme becerisine etkisi, Yayımlanmamış doktora tezi, Ankara Üniversitesi, Eğitim Bilimleri Enstitüsü, Ankara.

Bildiren, A. (2017). Reliability and validity study for the coloured progressive matrices test between the ages of 3-9 for determining gifted children in the pre-school period. Journal of Education and Training Studies, 5(11), 13-20. https://doi.org/10.11114/jets.v5i11.2599

Bildiren, A., Kargın, T., \& Korkmaz, M. (2017). Renkli Progresif Matrisleri Testi'nin 4-6 yaş aralığında güvenirlik ve geçerlik çalışması. Turkish Journal of Giftedness \& Education, 7(1), 19-38.

Bloom, B. S. (1982). The role of gifts and markers in the development of talent. Exceptional Children, 48(6), 510-521. https://doi.org/10.1177/001440298204800607

Burns, D. E. (1990). Pathways to investigative skills. Mansfield Center, CT: Creative Learning.

Cao, T. H., Jung, J. Y., \& Lee, J. (2017). Assessment in gifted education: A review of the literature from 2005 to 2016. Journal of Advanced Academics, 28(3), 163-203. https://doi.org/10.1177/1932202X17714572

Carman, C. A., Walther, C. A., \& Bartsch, R. A. (2018). Using the Cognitive Abilities Test (CogAT) 7 nonverbal battery to identify the gifted/talented: An investigation of demographic effects and norming plans. Gifted Child Quarterly, 62(2), 193-209. https://doi.org/10.1177/0016986217752097

Clark, B. (2002). Growing up gifted: Developing the potential of children at home and at school (6th ed.). Upper Saddle River, NJ: Merrill-Prentice Hall.

Cohen, L. N. (1989). Understanding the interests and themes of the very young gifted child. Gifted Child Today, 12(4), 6-9. https://doi.org/10.1177/107621758901200402

Cotton, S. M., Kiely, M. P., Crewther, D. P., Thomson, B., Laycock, R., \& Crewther, S. G. (2005). A normative and reliability study for the Raven's Coloured Progressive Matrices for primary school aged children from Victoria. Australia Personality and Individual Differences, 39, 647-659. https://doi.org/10.1016/j.paid.2005.02.015

Crano, W. D., \& Brewer, M. B. (2002). Principles and methods of social research (2nd ed.). Mahwah, NJ, US: Lawrence Erlbaum Associates Publishers.

Çelik, C., Erden, G., Özmen, S., \& Tural Hesapçığlu, S. (2017). Comparing two editions of Wechsler Intelligence Scales and assessing reading skills in children with attention deficit and hyperactivity disorder. Turkish Journal of Psychiatry, 28(2), 104-116.

Dağlığlu, E. H. (2002). Anaokuluna devam eden beş-altı yaş grubu çocuklar arasından matematik alanında üstün yetenekli olanların belirlenmesi. Yayınlanmamış doktara tezi. Hacettepe Üniversitesi Sağlık Bilimleri Enstitüsü Çocuk Gelişimi ve Eğitimi Anabilim Dalı, Ankara.

Davis, G. A., \& Rimm, S. B. (2004). Education of the gifted and talented (5th ed.). Boston, MA: Pearson Education Press.

Gagne, F. (2003). Transforming gifts into talents: The DMGT as a developmental theory. In N. Colangelo \& G. A. Davis (Eds.), Handbook of gifted education (3rd ed., pp. 60-74). Boston: Pearson Education.

Gardner, H. (2003). Multiple intelligences after twenty years. American Educational Research Association, Chicago, Illinois, 21.

İnal, G. (2011). Bilişsel yetenekler testi form-6’nın geçerlik güvenirlik çallş̧ması ve altı yaş çocuklarının bilişsel yeteneklerine muhakeme eğitim programının etkisinin incelenmesi. Yayımlanmamış doktora tezi, Gazi Üniversitesi, Eğitim Bilimleri Enstitüsü, Ankara.

İnal, G., \& Ömeroğlu, E. (2011). Bilişsel yetenekler testi form 6'nın 61-72 aylar arasında olan çocuklar için 
geçerlik güvenirlik çalışması. Kuramsal Eğitimbilim Dergisi, 4(2), 198-207.

Johnsen, S. (2009). Best practices for identifying gifted students. Principal, 88, 8-14.

Johnsen, S. K. (2008). Identifying gifted and talented learners. In F. A Karnes \& S.R. Stephens (Eds.), Achieving excellence: Educating the gifted and talented (pp. 135-153). Upper Saddle River, NJ: Pearson/Merrill Prentice Hall.

Karadăg, F. (2015). Okul öncesi dönemde potansiyel üstün zekalı çocukların belirlenmesi. Yayınlanmamış yüksek lisans tezi. Dokuz Eylül Üniversitesi Eğitim Bilimleri Enstitüsü Özel Eğitim Anabilim Dalı Özel Eğitim Bilim Dalı, İzmir.

Karadağ, F., Karabey, B., \& Pfeiffer, S. (2016). Identifying gifted preschoolers in Turkey: The reliability and validity of the Turkish-translated version of the Grs-Preschool/Kindergarten Form. Journal of Education and Training Studies, 4(10), 8-16. https://doi.org/10.11114/jets.v4i10.1686

Karasar, N. (2006). Bilimsel Araştırma Yöntemi. Ankara: Nobel Yayınevi.

Karnes, F. A., Shaunessy, E., \& Bisland, A. (2004). Gifted students with disabilities: Are we finding them? Gifted Child Today, 27(4), 16-21. https://doi.org/10.4219/gct-2004-148

Kirschenbaum, R. (1998). Dynamic assessment and its use with underserved gifted and talented populations. Gifted Child Quarterly, 42(3), 140-147. https://doi.org/10.1177/001698629804200302

Kurt, E. (2008). Raven SPM Plus Testi 5.5-6.5 yaş geçerlik, güvenirlik, ön norm çalışmalarına göre üstün zekalı olan ve olmayan ögrencilerin erken matematik yeteneklerinin karşılaştırılması. Yayınlanmamış yüksek lisans tezi, İstanbul Üniversitesi Sosyal Bilimler Enstitüsü, İstanbul.

Lewis, J., DeCamp-Fritson, S., Ramage, J., McFarland, M., \& Archwamety, T. (2007). Selecting for ethnically diverse children who may be gifted using Raven's Standard Progressive Matrices and Naglieri Nonverbal Abilities Test. Multicultural Education, 15, 38-42.

Liu, Y. H., \& Lien, J. (2005). Discovering gifted children in pediatric practice. Journal of Developmental and Behavioral Pediatrics, 26, 366-369. https://doi.org/10.1097/00004703-200510000-00005

Lohman, D. F., \& Hagen, E. (2002). Research handbook: Cognitive Abilities Test Form 6-all levels. Itasca, Illinois: Riverside Publishing.

Lohman, D. F., \& Hagen, E. (2003). Interpretive guide for teachers and counselors: cognitive abilities test Form 6-all levels. Itasca, Illinois: Riverside Publishing.

Lohman, D. F., Korb, K. A., \& Lakin, J. M. (2008). Identifying academically gifted English-language learners using nonverbal tests: A comparison of the Raven, NNAT, and CogAT. Gifted Child Quarterly, 52(4), 275-296. https://doi.org/10.1177/0016986208321808

Louis, B., Lewis, M., \& Feiring, C. (1991). Identification of minority inner-city gifted preschool children. Paper presented at the ACYF Research Conference, Crystal City, VA.

McWilliam, R. A. (2005). Assessing the resource needs of families in the context of early intervention. In M. J. Guralnick (Ed.), A developmental systems approach to early intervention: National and international perspectives (pp. 215-234). Baltimore, MD: Paul H. Brookes.

MEB. (2015). Kaufman Brief Intelligence-2 (KBİT-2) Testi ve Wechsler Sözel Olmayan Yetenek Testi (WNV) Retrieved

from http://orgm.meb.gov.tr/www/weschler-nonverbal-testi-wnv-ve-kaufman-brief-intelligence-2-kbit-2-testlerini n-uygulayici-yetistirme-kursu/icerik/483

Naglieri, J. A., \& Ford, D. Y. (2005). Increasing minority children's participation in gifted classes using the NNAT: A response to Lohman. Gifted Child Quarterly, 49, 29-36. https://doi.org/10.1177/001698620504900104

National Association for Gifted Children [NAGC] \& Council for Exceptional Children [CEC]. (2006). NAGCCEC Teacher knowledge \& skill standards for gifted and talented education. Retrieved from www.nagc.org/...standards/final\%20standards\%20(2006).pdf

Öner, N. (1997). Türkiye’ de kullanılan psikolojik testler. İstanbul: Boğaziçi Üniversitesi Yayınları.

Özgüven, İ. E. (2007). Psikolojik Testler. Ankara: Pdrem Yayınları.

Pfeiffer, S. I. (2002). Identifying gifted and talented students: Recurring issues and promising solutions. Journal 
of Applied School Psychology, 19(1), 31-50.

Pfeiffer, S. I. (2003). Challenges and opportunities for students who are gifted: What the experts say. Gifted Child Quarterly, 47(2), 161-169. https://doi.org/10.1177/001698620304700207

Pfeiffer, S. I., \& Jarosewich, T. (2003). The gifted rating scales. San Antonio, TX: Psychological Corporation.

Pfeiffer, S. I., \& Petscher, Y. (2008). Identifying young gifted children using the gifted rating scales$\begin{array}{lllll}\text { preschool/kindergarten form. Gifted Child } & \text { Quarterly, }\end{array}$ https://doi.org/10.1177/0016986207311055

Porter, L. (2005). Gifted young children (2nd ed.). Berkshire, England: Open University Press.

Raven, J., Raven, J. C., \& Court, H. (1998). Coloured progressive matices (1998 Edition). USA: Harcourt Assesment.

Renzulli, J. S. (1984). The Three Ring Conception of Giftedness: A Developmental Model for Creative Productivity.

Renzulli, J. S., Smith, L. H., White, A. J., Callahan, C. M., Hartman, R. K., \& Westberg, K. L. (2002). Scales for rating the behavioral characteristics of superior students (Rev. ed.). Mansfield Center, CT: Creative Learning Press.

Robinson, N. M. (1987). The early development of precocity. Gifted Child Quarterly, 31(41),161-164. https://doi.org/10.1177/001698628703100406

Robinson, N. M., \& Weimert, L. J. (1990). Selection of candidates for early admission to kindergarten and first grade. In W. T. Southern \& E. D. Jones (Eds.), The academic acceleration of gifted children (pp. 29-50). New York, NY: Teachers College Press.

Sandall, S., Hemmeter, M. L., Smith, B. J., \& McLean, M. E. (2005). The division for early childhood [DEC]-Recommended practices: A comprehensive guide for practical application in early intervention/early childhood special education. Longmont, CO: Sopris West.

Sankar-DeLeeuw, N. (2002). Gifted preschoolers: Parent and teacher views on identification, early admission, and programming. Roeper Review, 24(3), 172-177. https://doi.org/10.1080/02783190209554174

Schroth, S. T., \& Helfer, J. A. (2008). Identifying gifted students: Educator beliefs regarding various policies, processes, and procedures. Journal for the Education of the Gifted, 32(2), 155-179. https://doi.org/10.4219/jeg-2008-850

Selçuk-Bozkurt, Ö. (2007). Okul öncesi dönemde ögrretmenleri tarafindan yaşıtlarına göre üstün ve özel yetenekli olarak aday gösterilen çocukların gelişim özelliklerinin incelenmesi. Yayımlanmamış yüksek lisans tezi, Hacettepe Üniversitesi, Sağlık Bilimleri Enstitüsü, Ankara.

Shaklee, B., \& Hansford, S. (1992). Identification of underserved populations: Focus on preschool and primary children. OH: Columbus, Ohio State Department of Education.

Silverman, L. K. (1997-2004). Characteristics of giftedness scale: A review of the literature. Retrieved from www.gifteddevelopment.com/Articles/Characteristics_Scale.htm

Smutny, J. F. (Ed.). (1998). The young gifted child: Potential and promise, an anthology. Cresskill, NJ: Hampton Press.

Sternberg, R. J. (2003). Giftedness according to the theory of successful intelligences. In N. Colangelo \& G. A. Davis (Eds.), Handbook of gifted education (3rd ed., pp. 88-99). Boston: Pearson Education.

Sternberg, R. J. (2018). 21 Ideas: A 42-Year Search to Understand the Nature of Giftedness. Roeper Review, 40(1), 7-20. https://doi.org/10.1080/02783193.2018.1393609

Suveren, S. (2006). Anasınıfina devam eden çocuklar arasından üstün yetenekli olanların belirlenmesi. Yayınlanmamıs yüksek lisans tezi, Bolu Abant İzzet Baysal Üniversitesi, Sosyal Bilimler Enstitüsü, İlköğretim anabilim dalı, Bolu.

Tannenbaum, A. J. (1992). Early signs of giftedness: Research and commentary. Journal for the Education of the Gifted, 15(1), 104-133. https://doi.org/10.1177/016235329201500202

Walker, B., Hafenstein, N. L., \& Crow-Enslow, L. (1999). Meeting the needs of gifted learners in the early childhood classroom. Young Children, 54(1), 32-36.

Wolfle, J. (1989). The gifted preschooler: Developmentally different, but still three or four years old. Young 
Children, 44(3), 41-08.

Wortham, S. C. (2005). Assessment in early childhood education (4th ed.). Upper Saddle River, NJ: Pearson.

Yang, Y. (2009). Identification of young, gifted children: An analysis of instruments and recommendations for practice. A paper presented at 18th World Council for Gifted and Talented Children Conference, Vancouver, British, Columbia, Canada. Retrieved from geri.education.purdue.edu/PDF\%20Files/yang_WCGTC_paper_mg7.pdf

Yiğit, İ., Çelik, C., \& Erden, G. (2017). Üstün Yetenekli Çocuklarda WÇZÖ-R ve WÇZÖ-IV* Zekâ Puanlarının Karşılaştırılması. Türk Psikoloji Dergisi, 32(79), 80-91.

https://www.projeiq.com/

\section{Copyrights}

Copyright for this article is retained by the author(s), with first publication rights granted to the journal.

This is an open-access article distributed under the terms and conditions of the Creative Commons Attribution license (http://creativecommons.org/licenses/by/4.0/). 